\title{
The Contribution of Movie Clips to Idiom Learning Improvement of Iranian EFL Learners
}

\author{
Omid Tabatabaei \\ Department of English, Najafabad Branch, Islamic Azad University, Najafabad, Iran \\ Email: tabatabaeiomid@yahoo.com \\ Firooz Reisi Gahroei \\ Department of English, Najafabad Branch, Islamic Azad University, Najafabad, Iran
}

\begin{abstract}
Learning idioms in a foreign language in which there are numerous problems in exposing the learners to authentic situations has faced many pedagogical difficulties. Many researchers (Gibbs, 1992: Honeck, 1997: Simpson \& Mendi, 2003) have tried to know more about the process of idiom learning and the effect of mother tongue on understanding idioms, because idioms are among the difficult areas of learning a foreign or second language. This study was an attempt to examine the impact of applying movie clips including idioms on the quality of idiom learning. To this end, 100 gifted high school students, aged between 16 and 18 were selected. Then, an Oxford Placement Test (OPT) was administered to select 60 intermediate students. Due to the matched-pair technique, they were divided into two equal experimental and control groups. In order to find out whether the students have any prior knowledge about the new idioms, a pre-test including an idiom multiple choice test was used. The control group was taught $\mathbf{3 0}$ idioms conventionally using synonyms and antonyms. The experimental group received the treatment and the idioms were taught using movie clips. After 10 weeks an idiom multiple choice test based on the materials taught was administered to both groups. Then, 60 students and 10 high school English teachers completed an attitudinal questionnaire reflecting their attitudes towards learning idioms through the suggested way. The statistical analyses of the collected data showed that there was a significant difference between the obtained means of the two groups, meaning that, the experimental group outperformed the control one. Therefore, teachers, students, test makers, test designers, and materials developers should consider the effectiveness of using movie clips and films in L2 idiom learning/teaching.
\end{abstract}

Index Terms - EFL learners, figurative language, idiom learning, movie clips

\section{INTRODUCTION}

Learning is a cognitive process that involves conscious and active behavior. Students look for similarities and differences between new information and prior knowledge, and in this way are able to effectively assimilate new learning into existing cognitive structures (Piaget,1980).

Language, according to Hudson (1980), is at the center of human life and the ability to learn language is among the greatest mental achievements of mankind. Studies of language in television news programs have found that speakers use one unique metaphor for every 25 words (Graesser, Mio, \& Millis, 1989). Linguists and educators in various language-related fields have been able to understand, to some extent, what language is and how it is learned as a second or foreign language and how it can be taught. Language is composed of many different parts each of which is important in learning. Learning and understanding idioms, metaphoric and idiomatic expressions have long played an important role in the English language. In fact, the use of idioms is so widespread that understanding these expressions is essential to successful communication, whether in listening, speaking, reading, or writing.

Gibbs (1992) believes that by developing a clear understanding of figurative language, students can further comprehend texts that contain metaphorical and lexical meanings beyond the basic word level. Honeck (1997) notes that figurative language is language that means one thing literally but is taken to mean something different and it is a special aspect of language. Gibbs (1980) holds that a strong knowledge of idioms will help the students to be better speakers and negotiators. They will also be in a better position to use their knowledge in appropriate contexts. So, it would be true if we conclude that the amount of the frequency of idioms is an important aspect of vocabulary acquisition and language teaching (Fernando, 1996). Native speakers of a language use idioms all the time. Idiomatic usage is so common in every language, and of course in English, that it seems very difficult to speak or write without using idioms.

Films are motivating for EFL/ESL teaching because they embody the notion that "a film with a story that wants to be told rather than a lesson that needs to be taught "(Ward \& Lepeintre, 1996). Films are such valuable and rich resources for teaching because they present colloquial English in real life contexts rather than artificial situation; an opportunity of being exposed to different native speaker voices, slangs, reduced speeches, stress, accents, and dialects, (Stempleski, 2000). 
It is also interesting to be aware of this fact that whether knowing only the literal meaning of the idioms will enable the students to extend that literal meaning to figurative sense in general reading. In other words, this major question comes to mind: Does watching movie clips including idioms have any significant effect on L2 students' ability to grasp the figurative meaning of idioms?

In Iran there are special schools designed merely for brilliant and talented students such as, National Organization for Development of Exceptional Talents (NODET). The students enter these schools through entrance exams. Because of the high level of students' intelligence, the level of teaching and the materials taught in these schools are somehow more advanced than the ordinary ones. In English classes, extra hours are devoted to extracurricular activities. Due to the students' interests and desires, different related activities such as reading various texts, watching films, listening to stories, discussions, giving lectures, hot seat, translating proverbs, idioms, and poems are performed.

The purpose of the present study which has focused on two ways of teaching idiomatic expressions, using movie clips including the idioms and the conventional way of teaching the idioms using synonyms - antonyms, was to explore whether movie clips including the idioms can help learners comprehend their figurative meaning more effectively.

\section{REVIEW OF THE RELATED LITERATURE}

In a study Irujo (1986) states that in a second language learning classroom all the learners must be prepared to meet the challenge of idioms occurring frequently in spoken and written English.

In another study Fine (1988) compared a foreign-language learner with a child L1 acquisition. One area that caused problem was idioms learning. He taught the idioms accompanied with their stories behind, so the learners got the meaning of idioms in a better way. Boers (1992) in his article, 'Raising metaphoric awareness' states that by developing a clear understanding of figurative language, students can further comprehend texts that contain metaphorical and lexical meanings beyond the basic word level.

According to Cooper (1998) teachers think one of the reasons their students made up dialogues that always seemed so unnatural to them is that the students used the idioms without regarding their pragmatic function in the discourse. Due to Cooper (1999), idiom study presents a special language problem for all language learners because the figurative meaning is unpredictable. Nippold, Maron, \& Schwarts (2001) findings show that factors such as culture, context, academic literacy (reading, writing, and language ability) and familiarity influence significantly students' comprehension of idioms. In another study Simpson and Mendis (2003) mention that information on the frequency of idioms in academic spoken American English has helped language teachers which idioms might be useful to teach to ESL/EFL students. Sprenger et al. (2006) in their study report the lexical representation of idioms contains information specifying the syntactic properties of these expressions.

Cognitive semantic studies of figurative language (Gibbs, 1994: Kovecses, 1990: Lakoff, 1987) have shown that considerable numbers of idioms are not completely arbitrary. Figurative idioms meaning are not fully predictable on the basis of a literal reading. For example, the expression Time flies can be motivated by the conceptual metaphor TIME IS A MOVING OBJECT (also evidenced by statements such as I'm falling behind schedule again, The holidays are approaching and Those days are over).

Film communication offers links between classrooms and society. Films can help explore cultural context, maybe integrated easily into the curriculum, are entertaining. And allow flexibility of materials and teaching techniques, (Wood, 1995).

In the Clifford et al.'s (1995) study, children's knowledge gain about a topic after watching a science film was also examined. The participating primary school and middle school children had different knowledge levels before watching the science program, and both age groups benefited from watching it. This benefit was found in terms of open-ended questions. Interestingly, there were no differences in the amount of knowledge growth between the age groups, indicating that prior knowledge does not determine the amount of learning.

According to Massi \& Merrio (1996) good films can serve as valuable pedagogical aids, both for classroom use and self-study.Regarding the power of films as a medium, Massi, \& Merrio (1996) believe that it can be exploited in a number of ways. One possible use of films in the language program is to promote new ideas and expand the learner's horizons. In a content-based syllabus, for instance, a particular film can be used to vividly illustrate situations which are unfamiliar or inaccessible and provide the learner with a stimulus which serves as a springboard for further discussion of an issue.

Fisch et al.'s study (Fisch et al., 2001) relies on one of the few theoretical models about learning with educational television (Fisch, 2000), although this model is primarily concerned with comprehension. It is postulated that the comprehension of an educational film depends not only on the comprehensibility of the educational content, but also on the narrative content in which the educational messages are embedded (Fisch et al., 2001).

Secles, Herron \& Tomasello (1992) explain", viewing the video and movie clips would enhance students' learning of vocabulary and idiomatic structures because of the contextualized presentation of the video", and viewing English Speaking Foreign Films of course gives necessary exposure and experience.

A study (Beuscher, Robers, \& Schnider, 2005) revealed a significant increase in specific knowledge as well as strong age effects of test format. Children aged 6,8 and 10 years were shown a short film about sugar production and 1 week later individually questioned about it using different test formats: free recall, open-ended questions and recognition 
questions. Expectedly, older children outperformed younger children and open-ended and recognitions yielded more correct information than free recall. Although people are probably aware that popular history films are partially fictionalized, previous research indicates that information from fiction is often integrated with real-world knowledge, which leads to learning and subsequent production of misinformation (Marsh \& Fazio, 2006). Quiang,H \& Wolff(2007) tried to explain the notion of using films, exposing students to the language has been explored and has been recognized as being more beneficial for students' communicative skills, rather than grammar and such. Many The entertainment value of a film increase interest in the topic, which can boost people's motivation to learn (Silvia, 2008).

Fazly, Cook, \& Stevenson (2009) looked into the usefulness of some of the identified linguistic properties of idioms for their automatic recognition. Specifically, they developed statistical measures that each model presents a specific property of idiomatic expressions by looking at their actual usage patterns in text. The researchers used these statistical measures in a type-based classification task where they automatically separate idiomatic expressions (expressions with a possible idiomatic interpretation) from similar-on-the-surface literal phrases (for which no idiomatic interpretation is possible).

In the previous studies, none of the researchers paid attention to idiom learning through watching films or movie clips. In this study, however, it has been attempted to investigate whether or not showing films or movie clips including idioms has any effects on the acquisition of idioms by EFL Iranian learners.

\section{A. Teaching Idioms}

One important component of successful language learning is the mastery of idiomatic forms of expressions including idioms, collocations, and sentence phrases, collectively referred to as formulaic sequence (Wray, 2000). Irujo (1986) believes that teaching idioms requires a multi-faceted approach. Sometimes, a teacher needs to explain the grammar of idioms, such as the difference between separable and non-separable verbal idioms.

\section{B. Approaches to Teach Formulaic Language}

The first approach is devoted to Willis (1990) who favors "procedures which make [the] patterns salient' (personal communication). He believes that "we need to help students to notice patterning and to speculate about them". His approach introduces formulaic sequence incidentally, as part of the body of data used to demonstrate words in their customary usage. The rational is clear and sensible:

The commonest pattern in English occurs again and again with the commonest words in English. If we are to provide learners with language experience which offers exposure to the most useful patterns of the language, we might as well begin by researching the most useful words in the language (Willis, 1990, p.38)

The second approach proposed by Nattinger \& Decarrio (1992) deals with the interactional functions accompanied by individual examples of common formulaic sequences. They focus on their usefulness in teaching conversation and recommend the following exercises:

- Pattern practice drills using fixed routines, to develop confidence and fluency;

- Increased variation " allowing them to analyze the pattern further" (Nattinger and DeCarrio, 1992 p.32)

The third approach which belongs to Lewis (1993), downgrades the significance of the single words as a unit and prefers the broader term like lexical item. In this approach, the lexical phrase is important. So he selects lexical phrases on the basis of their "archetiicality" and his aim is to provide:

- "a large vocabulary, if low level students are initially unable to grammaticalize it".

- "balance between relatively rare words carrying considerable meaning and relatively wide and frequent pattern with low meaning content"(Lewis 1993 p.58).

\section{STATEMENT OF THE PROBLEM}

Every language has phrases or sentences that cannot be understood literally. Even if you know the meaning of all the words in a phrase and understand the grammar completely, the meaning of the phrase may still be confusing. Many clichés, proverbs, idioms, slang phrases, phrasal verbs, and common sayings offer this kind of problem. For long, learning idioms has always been a big problem for students especially the foreign language learners. Any foreign language learner knows that idioms are essential and their misunderstanding leads to a feeling of insecurity.

Boers (1992) states that it is inevitable for students to face problems dealing with idioms by knowing this fact that their meanings are not clear and cannot be attained directly at the first look. Because of the tricky nature of idioms, students face problems dealing with them.

Educational films for students aim to impart knowledge about a certain topic like idiom learning. In this study it will be shown how much and what kind of idioms students can remember from educational films and how idiom acquisition through films will be enhanced.

Iranian students studying English as a foreign language have no desirable and practical conditions in their schools, because they don't have sufficient exposure to authentic situations needed to become proficient enough at English language components like using and learning idioms. Movie clips and films offer endless opportunities of sound activities for developing fluency. The key to use films and movies effectively mainly lies in the teacher's ability in preparing students to receive the film's message, (King, 2002). 
Very little has been done to investigate the effectiveness of using films and movie clips on idiom learning in Iran. Thus, it has been hypothesized that teaching idioms by using movie clips including the idioms might facilitate their learning. In addition, it might enable the learners to go beyond the literal meaning of the idioms when supported by appropriate visualizers like films and movie clips.

\section{RESEARCH QUESTIONS}

The present study attempted to investigate appropriate answers to the following questions:

1. Does watching the movie clips including the idioms facilitate idioms learning of Iranian high school EFL learners?

2. Do L2 learners have positive attitude towards the application of movie clips including the idioms in teaching new idioms?

3. Do L2 teachers have positive attitude towards the application of movie clips including the idioms in teaching new idioms?

\section{RESEARCH HYPOTHESES}

1. Watching movie clips including the idioms doesn't facilitate idioms learning of Iranian high school EFL learners.

2. L2 learners have no positive attitude towards the application of movie clips including the idioms in teaching new idioms.

3. L2 teachers have no positive attitude towards the application of movie clips including the idioms in teaching new idioms.

\section{OBJECTIVES OF THE STUDY}

Needless to say, it is important for teachers to make learning of the idioms easier and more effective. Different teachers use different methods for teaching idioms. As it was mentioned earlier idioms are among the difficult areas of learning. Teachers may compare the idioms of two languages and ask students to find appropriate equivalence for them in their mother tongue. It is also probable that they use the idioms in related contexts. These teachers believe that the cotext can help the students infer the meanings of idioms and the retention of them becomes possible in exams. There are also teachers who classify the idioms due to their themes to make them easier for efficient learning. There are educational books that are designed according to this fact.

In this study, one more solution was proposed for the mentioned problem. Words and phrases have been born based on the society expectations. Idioms are no exception. In this study, it was suggested that if the language learners watched movie clips or films including the idioms, they could learn the idioms in a more effective way. Thus, the purpose of this study was to make it clear whether watching movie clips including the idioms could be effective.

\section{METHODOLOGY}

\section{A. Participants}

An original population pool of 100 Iranian high school students was randomly selected. Then, an Oxford Placement Test (OPT) was administered to select 60 students with intermediate proficiency level. Next, due to the matched-pair technique, they were divided into two groups, one experimental and one control, identical in number. All the participants in the research were high school boys, aged between 16 and 18. Ten high school English teachers also participated in the study to offer their attitudes towards teaching idioms.

\section{B. Instrumentation}

This study proceeded in applying three instruments: First, a proficiency test was administered to screen the subjects and homogenize them based on their level of proficiency.

Second, an achievement test for the final measurement and evaluation was conducted. It included thirty idiom multiple-choice items, with four alternatives for each sentence. It was designed in advance by the researcher through pilot studies. Based on the performance of the participants the characteristics of the individual items were determined and some items were revised, in order to ensure test replicability. The reliability of test was calculated by using KR-21 formula. The results showed a reliability index of (0.945). To determine the validity of the test the researcher asked some experts and English teachers to pass their comments on the content of the test. The test had a total of thirty points and the time allowance was thirty minutes.

Third, an attitudinal questionnaire including 15 items (see Appendix A) that would show the students' and teachers' attitudes towards learning English idioms was administered. The questionnaire used is Robert Gardner's (1985), Attitude/Motivation Test Battery (AMTB), which is made up of over 130 items, and its reliability and validity have already been confirmed (Gardner, 1985, 2005; Gardner \& Macintyre, 1991: Gardner \& Macintyre, 1983). The reliability of the questionnaire were determined through an exact pilot study. To determine the validity of the questionnaire the researchers asked some experts and English teachers to pass their comments on validity and content 
appropriateness of the questionnaire. The reliability of the questionnaire was calculated by using KR-21 formula ( $\mathrm{R}=.87$.

\section{Procedures}

To accomplish the purpose of the study, the following procedures were followed:

First, it was a selection of the subjects and administration of the Oxford Placement Test (OPT). Second, an idiom multiple-choice test which was constructed by the researchers was administered. This test was piloted to determine its validity and reliability. After getting the results of the Oxford Placement Test, the homogeneity of subjects was determined. In order to extract the outliners, the researcher included only those subjects whose scores were at intermediate proficiency level and they were assigned on two groups of experimental and control.

Before teaching the new idiom, the previous idioms were reviewed. The whole project of teaching took two and a half months. The students' tasks were to go over the idioms and make themselves ready for the test at the end of the term. In group A the idioms were taught by showing movie clips including the idioms. In group B the same idioms were taught only by teaching synonyms and antonyms of the new words in idioms. To exemplify, an example of two ways of teaching the idiom "between the devil and the dark blue sea" will follow:

Group A: In this group at first the researchers taught the idioms in movie clips. The researchers showed a clip to the students that included the idiom ' between the devil and the dark blue sea'. The students watched the clip two or three times in order to get the idiom. After that one of the researchers asked the students to write the idiom on a piece of paper.

Group B: For this group the researchers taught only the figurative meaning by providing a synonym for the idiom to be in a difficult situation - and then he wrote an example on the board. e.g.,: David had an important final test last week and his father was terribly sick, in fact he was between the devil and the dark blue sea. The purpose of giving this example was to make students familiar with the way to use the idiom in different situations.

In most of the American films the actors, actresses, and directors use the idioms in the episodes of the films. The researchers extracted some parts or clips of films and showed them to students. The comprehensibility, culture, appropriateness of content, and the comfort level of students needed to be taken into account in the process of selecting a film.

The idioms were chosen based on students' level of proficiency, culture, religion, interest, motivation, and practical feasibility. The final test that was the post-test of the study included twenty items. For every item there was a situation which could be completed just by one idiom out of the four idioms given in each items.

At the end, an attitudinal questionnaire was administered .Sixty students and 10 high school teachers completed in it in order to reflect their attitudes towards teaching and learning idioms using movie clips. It included 15 items. The attitude/motivation scale of the original 5-point Likert format of Gardner's Attitude/Motivation Test Battery (AMTB) Gardner, (1985) \& Clement et al.'s (1994) was adapted from ' strongly disagree ' to ' strongly agree '. The scales were coded as (Strongly Disagree $=1$, Disagree $=2$, Neutral $=3$, Agree $=4$, Strongly Agree = 5). The data from questionnaire was fed into the computer and then analyzed using SPSS. Descriptive statistics (mean, frequency, \& standard deviation) were computed for all items involved in the questionnaire of the study.

\section{RESULTS AND DISCUSSION}

Several statistical analyses were concluded to answer the research questions in this study.

This study required a comparison of two groups drawn from the population (third grade) senior gifted high school students in Shahrekord (a province in Iran).

\section{A. The Pretests}

After the administration of the Oxford Placement Test at the first session of the study, the subjects were divided into two intact groups of experimental and control. Then, in order to ascertain the homogeneity of the two groups, a t-test was run. Figure 8.1 indicates the graphical representation of the means and Table 1 shows the results of the t-test. 


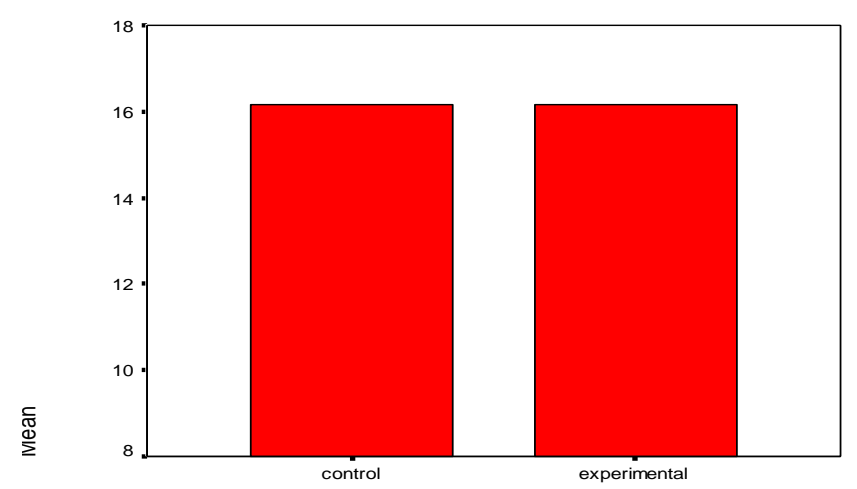

Figure 8.1. The Graphic Represetation of the Means on the OPT

TABLE 1.

THE RESULTS OF THE T-TEST ON THE OPT

\begin{tabular}{|l|l|l|l|l|l|}
\hline \multicolumn{6}{c|}{ THE RESULTS OF THE T-TEST ON THE OPT } \\
\hline Std. Error Mean & Std. Deviation & Mean & $\mathrm{N}$ & CODE & \\
\hline .322 & 1.763 & 16.17 & 30 & control group & OPTTESTT \\
.267 & 1.464 & 16.17 & 30 & experimental group & \\
\hline
\end{tabular}

TABLE 2.

THE RESULTS OF THE T-TEST ON THE OPT

\begin{tabular}{|c|c|c|c|c|c|c|c|c|}
\hline \multicolumn{5}{|c|}{ t-test for Equality of Means } & \multicolumn{2}{|c|}{$\begin{array}{l}\text { Levene's Test for Equality } \\
\text { of Variances }\end{array}$} & & \\
\hline $\begin{array}{l}\text { Std. Error } \\
\text { Difference }\end{array}$ & $\begin{array}{l}\text { Mean } \\
\text { Difference }\end{array}$ & $\begin{array}{l}\text { Sig. }(2- \\
\text { tailed) }\end{array}$ & df & $\mathrm{t}$ & Sig. & $\mathrm{F}$ & & \\
\hline .418 & .00 & 1.000 & 58 & .000 & .141 & 2.233 & $\begin{array}{l}\text { Equal variances } \\
\text { assumed }\end{array}$ & $\begin{array}{l}\text { OPTT } \\
\text { ESTT }\end{array}$ \\
\hline .418 & .00 & 1.000 & 56.104 & .000 & & & $\begin{array}{l}\text { Equal variances not } \\
\text { assumed }\end{array}$ & \\
\hline
\end{tabular}

As presented in Tables 1 and 2. the t-observed is .000 at the significant level of 1.000 which means the difference between the two groups is not statistically significant. Therefore, it can be concluded that the experimental group and the control group are homogeneous. In order to establish the homogeneity of groups in terms of idiom knowledge prior to the study, an idiom test comprising 30 multiple-choice items was administered to both groups as the pretest. Then, the performances of the students on this test were compared and analyzed applying another t-test. Figure 2 shows the graphic representation of the means and Tables 3 and 4. represent the results of the second t-test.

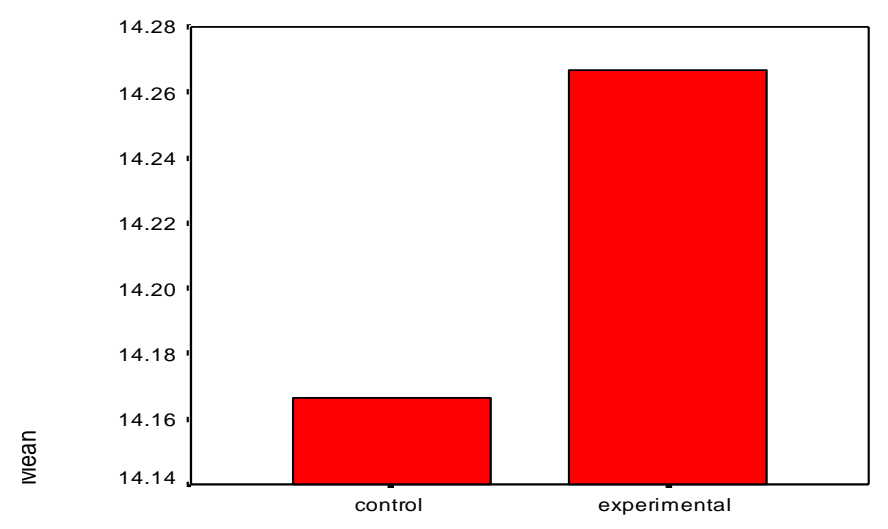

Figure 8.2. The Graphic Representation of the Means on the Pretest 
TABLE 3.

THE RESUlTS OF THE T-TEST ON THE PRETEST

\begin{tabular}{|c|c|c|c|c|c|}
\hline Std. Error Mean & Std. Deviation & Mean & $\mathrm{N}$ & CODE & \\
\hline .325 & 1.783 & 14.17 & 30 & control group & PRETEST \\
\hline .295 & 1.617 & 14.27 & 30 & experimental group2 & \\
\hline
\end{tabular}

TABLE 4.

THE RESUlTS OF THE T-TEST ON THE PRETEST

\begin{tabular}{|l|l|l|l|l|l|l|l|}
\hline \multicolumn{2}{|l|}{} & \multicolumn{3}{l|}{$\begin{array}{l}\text { Levene's Test for Equality } \\
\text { of Variances }\end{array}$} \\
t-test for Equality of Means \\
$\begin{array}{l}\text { Std. Error } \\
\text { Difference }\end{array}$ & $\begin{array}{l}\text { Mean } \\
\text { Difference }\end{array}$ & Sig. (2-tailed) & df & $\mathrm{t}$ & Sig. & $\mathrm{F}$ & \\
\hline .439 & -.10 & .821 & 58 & -.228 & .372 & .809 & $\begin{array}{l}\text { Equal variances } \\
\text { assumed } \\
.439\end{array}$ \\
\hline
\end{tabular}

The above table shows that the amounts of $\mathrm{t}$-observed is statistically not significant $(\mathrm{t}=0.228, \mathrm{p}=0.821)$; therefore, it can be claimed that two groups were homogeneous at the beginning of the experiment regarding their idiom prior knowledge.

\section{B. The Posttest}

After 10 sessions of instruction, the same idiom measure used as the pretest was administered to the groups as the posttest. In order to answer the first question of this study, another t-test was applied to the scores of the posttest. Figure 3 shows the graphic representation of the means and Tables 5 and 6. represent the results of this t-test.

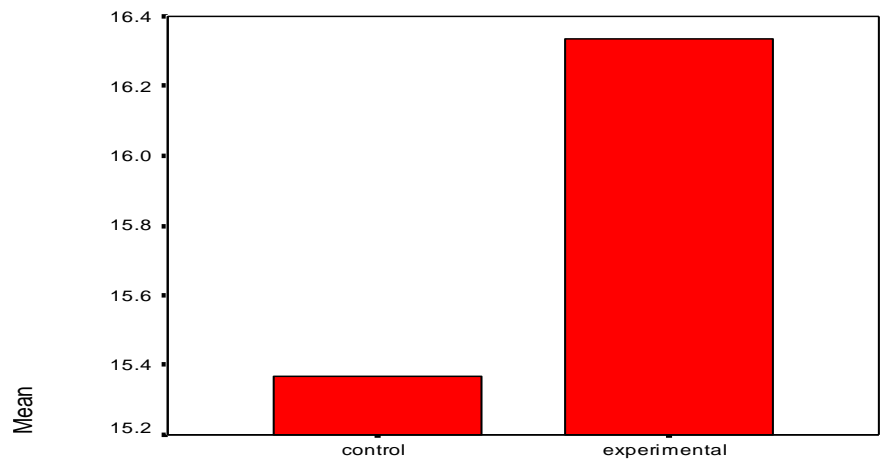

Figure 8.3. The Graphic Representation of the Means on the Posttest

TABLE 5.

THE RESULTS OF THE T-TEST ON THE POSTTEST

\begin{tabular}{|l|l|l|l|l|l|}
\hline Std. Error Mean & Std. Deviation & Mean & $\mathrm{N}$ & CODE & \\
\hline .260 & 1.426 & 15.37 & 30 & control group & POSTTEST \\
.216 & 1.184 & 16.33 & 30 & experimental group2 & \\
\hline
\end{tabular}

TABLE 6.

THE RESUlts OF THE T-TEST ON THE POSTTEST

\begin{tabular}{|c|c|c|c|c|c|c|c|c|}
\hline \multicolumn{5}{|c|}{ t-test for Equality of Means } & \multicolumn{2}{|c|}{$\begin{array}{l}\text { Levene's Test for } \\
\text { Equality of Variances }\end{array}$} & & \\
\hline $\begin{array}{ll}\text { Std. } & \text { Error } \\
\text { Difference } & \\
\end{array}$ & $\begin{array}{l}\text { Mean } \\
\text { Difference }\end{array}$ & Sig. (2-tailed) & df & $\mathrm{t}$ & Sig. & 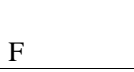 & & \\
\hline .338 & $\begin{array}{l}-.97 \\
-.97\end{array}$ & .006 & $\begin{array}{l}58 \\
56.107\end{array}$ & $\begin{array}{l}-2.856 \\
-2.856\end{array}$ & .172 & 1.913 & $\begin{array}{l}\text { Equal variances } \\
\text { assumed } \\
\text { Equal variances not } \\
\text { assumed }\end{array}$ & POSTTEST \\
\hline
\end{tabular}

As it is displayed in Tables 5. and 6. the amount of t-observed for the effect of teaching etymology on idiom learning is 2.856 at the probability level of .006 which shows a statistically significant difference between the two groups. In 
other words, the experimental group significantly outperformed the control group on the test of the effectiveness of teaching the etymology of idioms on idiom learning. This result safely rejects the null hypothesis which states that teaching the etymology of idioms has no effect on idiom learning, and it can be claimed that the treatment did affect the participants' idiom learning.

\section{Attitudinal Questionnaire}

At the end of the study, an attitudinal questionnaire including 15 items that showing the students' and teachers' attitudes towards learning English idioms was administered. In order to answer the second question of this study, the data received from the questionnaire fed into the computer then analyzed using SPSS. Descriptive statistics (mean, frequency, standard deviation) were shown in Table 7. Comparison between the mean scores of the questions illustrated that the students strongly agreed with questions $1,3,6,11$, and 12 .

The other questions $(2,7,8,9,10$, and 14) showed the students' moderate attitudes towards teaching and learning idioms among these 15 questions (Table 8.7.). In comparison to other questions, Q5 ( watching movie clips including the idioms can be important to the students for comprehension of idiomatic meaning), Q4 ( learning the idioms using movie clips can be important to the student because it makes long retention of idioms ) and Q15 ( learning the idioms using movie clips is important because without learning them masterly, the students feel something is missed) with mean scores of $3.32,3.31$, and 3.25 showed low level of having positive attitude towards idiom learning and Q13 (watching movie clips including the idioms can be important because the students can interpret the figurative meaning of the idioms by using visual aids) had the lowest mean in the questionnaire. It might be due to their lack of using films and movie clips including the idioms in their course of schooling.

TABLE.7.

\begin{tabular}{lccccccc} 
DESCRIPTIVE STATISTICS OF THE STUDENTS' ATTITUES TOWARDS IDIOM LEARNING & (N=60) \\
\hline Ite ms: & $\mathbf{1}$ & $\mathbf{2}$ & $\mathbf{3}$ & $\mathbf{4}$ & $\mathbf{5}$ & $\mathbf{M}$ & SD \\
\hline Q1: & 0 & 3 & 9 & 46 & 2 & 3.78 & 0.522 \\
Q2: & 0 & 5 & 17 & 34 & 4 & 3.61 & 0.682 \\
Q3: & 0 & 1 & 15 & 39 & 5 & 3.80 & 0.588 \\
Q4: & 0 & 2 & 22 & 33 & 3 & 3.31 & 0.630 \\
Q5: & 0 & 6 & 31 & 21 & 2 & 3.32 & 0.685 \\
Q6: & 0 & 0 & 7 & 48 & 5 & 3.96 & 0.430 \\
Q7: & 0 & 2 & 18 & 40 & 0 & 3.66 & 0.546 \\
Q8: & 0 & 3 & 15 & 38 & 4 & 3.72 & 0.682 \\
Q9: & 0 & 3 & 19 & 34 & 4 & 3.65 & 0.678 \\
Q10: & 0 & 7 & 24 & 27 & 2 & 3.40 & 0.743 \\
Q11: & 0 & 1 & 10 & 45 & 4 & 3.86 & 0.525 \\
Q12: & 0 & 0 & 16 & 40 & 4 & 3.80 & 0.503 \\
Q13: & 0 & 5 & 39 & 16 & 0 & 3.18 & 0.550 \\
Q14: & 0 & 2 & 18 & 37 & 3 & 3.68 & 0.522 \\
Q15: & 0 & 3 & 39 & 18 & 0 & 3.25 & 0.525 \\
Overall me an score & & & & & & $\mathbf{3 . 6 0}$ & \\
& & & & & & &
\end{tabular}

The overall mean score of 3.60 showed that the students had quite high positive attitude towards the application of movie clips in teaching new idioms. These results safely reject the second null hypothesis which states that L2 learners have no positive attitude towards the application of movie clips in teaching new idioms, and it can be claimed that the L2 learners have positive attitude towards the application of movie clips in teaching new idioms. Descriptive statistics (mean, frequency, \& standard deviation) of the teachers' attitudes towards the application of movie clips in teaching new idioms were shown in Table 7. Comparison between the mean scores of the questions illustrated that the teachers were strongly agree with questions $1,2,3,4,6,7,8,11$, and 12 .

TABLE.8.

\begin{tabular}{cccccccc} 
DESCRIPTIVE STATISTICS OF THE TEACHERS' ATTITUDES TOWARDS IDIOM LEARNING (N = 10$)$ \\
\hline Items: & $\mathbf{1}$ & $\mathbf{2}$ & $\mathbf{3}$ & $\mathbf{4}$ & $\mathbf{5}$ & $\mathbf{M}$ & SD \\
\hline Q1: & 0 & 0 & 0 & 3 & 7 & 4.70 & 0.483 \\
Q2: & 0 & 0 & 0 & 4 & 6 & 4.60 & 0.516 \\
Q3: & 0 & 0 & 0 & 3 & 7 & 4.70 & 0.483 \\
Q4: & 0 & 0 & 0 & 5 & 5 & 4.50 & 0.527 \\
Q5: & 0 & 0 & 0 & 6 & 4 & 4.40 & 0.516 \\
Q6: & 0 & 0 & 0 & 3 & 7 & 4.70 & 0.483 \\
Q7: & 0 & 0 & 0 & 3 & 7 & 4.70 & 0.483 \\
Q8: & 0 & 0 & 0 & 5 & 5 & 4.50 & 0.527 \\
Q9: & 0 & 0 & 0 & 6 & 4 & 4.40 & 0.516 \\
Q10: & 0 & 0 & 0 & 10 & 0 & 4.00 & 0.000 \\
Q11: & 0 & 0 & 0 & 2 & 8 & 4.80 & 0.422 \\
Q12: & 0 & 0 & 1 & 1 & 8 & 4.70 & 0.675 \\
Q13: & 0 & 0 & 2 & 8 & 0 & 3.80 & 0.422 \\
Q14: & 0 & 0 & 3 & 6 & 1 & 3.80 & 0.632 \\
Q15: & 0 & 0 & 2 & 7 & 1 & 3.90 & 0.568 \\
Over all mean score & & & & & 4.41 &
\end{tabular}


The other questions $(5,9,10$, and 15) showed the teachers' moderate attitudes towards te idioms using movie clips(Table 8). In comparison to other questions Q13 and Q14 obtained the lowest mean scores (3.80) in the questionnaire. The overall mean score of 4.41 showed that the teachers had high positive attitudes towards the application of movie clips in teaching new idioms. The results of the study safely rejects the third null hypothesis which suggests that L2 teachers have no positive attitudes towards the application of movie clips in teaching new idioms, and it can be concluded that L2 teachers have positive attitudes towards the application of movie clips in teaching new idioms so the third hypothesis is retained.

\section{DISCUSSION}

The main purpose of this study was to explore the effects of teaching the movie clips including the idioms on idiom learning. In this regard, a t-test was conducted to probe the first question in this study. The results revealed that there was a significant difference between the means of the experimental and control groups. Therefore, it can be concluded that using movie clips including the idioms has a significant effect on idiom learning of Iranian EFL high school students. In order to answer the second and the third questions an attitudinal questionnaire was administered. The results showed that both students and English teachers had positive attitudes towards the application of movie clips in teaching new idioms.

This finding is compatible with some of the empirical studies conducted earlier and reported in literature review. Wood (1995) mentioned that film communication offers links between classroom, society, and films can help explore cultural context, and they also allow flexibility of materials and teaching techniques. Boer (1992) in his study states that by developing a clear understanding of figurative language, students can further comprehend texts that contain metaphorical and lexical meanings. Simpson \& Mendis (2003) in their study found that information on the frequency of idioms in academic spoken American English helped language teachers which idioms might be useful to teach EFL/ESL students.

This finding is also in support of Quiang, $\mathrm{H} \&$ Wolff (2007) views who suggested that exploring the notion of using films, and exposing students to the language are given the learners the chance to become acquainted with the target language and assimilate simple English sentence structure.. All of these researchers claim that teaching etymology not only facilitates idiom learning but it makes it a meaningful learning experience.

\section{Conclusion}

The results of the present study seem to support the hypotheses formulated in this research. The first one is, the uses of idiom etymologies have positive effect on idiom learning of third-grade senior talented high school students. The results of the questionnaires used in this study supported the second and third hypotheses that the students and the English teachers have positive attitudes towards the application of etymology in teaching new idioms.

The researchers tried to investigate the potential usefulness of idiom etymologies as useful strategy in the inclusion of more practical aspects of idiom learning into language classroom.

\section{APPENDIX SURVEY QUESTIONNAIRE (ENGLISH LEARNING MOTIVATION SCALE)}

Below are a number of statements with which some people may agree and some may not. We would like you to indicate your opinion about each statement by ticking the boxes below which best indicates the extent to which you disagree or agree with that. We would like you to be as accurate as possible since the success of this investigation depends upon it.

Gender: Age: Class: School:

1= Strongly Disagree; 2= Disagree; 3= Neutral; 4= Agree; 5= Strongly Agree

Before taking it, please, take the following comments into account:

1) - It is very important that you write down the $\underline{\text { FIRST }}$ answer that comes to your mind.

2) - Please, $\underline{D O N O T}$ go back to correct the answer you have written.

3) - Please, $\underline{D O N O T}$ discuss the questions with other people while completing it. 
1. Watching movie clips including the idioms can be important to the students to raise their awareness of idioms.

$$
1-\square \quad 2-\square \quad 3-\square \quad 4-\square 5-\square
$$

2. Using movie clips including the idioms is highly important to the students because the students can use idioms better when keeping in touch with foreign friends and acquaintances.

$$
1-\square \quad 2-\square \quad 3-\square \quad 4-\square \quad 5-\square
$$

3. Applying movie clips including the idioms can be important to the students because it will make the students understand and become more knowledgeable.

$$
1-\square \quad 2-\square \quad 3-\square \quad 4-\square \quad 5-
$$

4. Learning the idioms using movie clips can be important to the students because it leads to long retention of idioms.

$$
1-\square \quad 2-\square \quad 3-\square \quad 4-\square \quad 5-\square
$$

5. Watching movie clips including the idioms can be important to the students for comprehension of idiomatic meaning.

$$
\text { 1- } \square \quad 2-\square \quad 3-\square \quad 4-\square \quad 5-\square
$$

6. Learning the idioms via movie clips is important to the students because it helps a well- educated person to use the idioms more efficiently.

7. Learning the idioms through movie clips is not a waste of time.

$$
1-\square \quad 2-\square \quad 3-\square \quad 4-\square \quad 5-\square
$$

$$
1-\square \quad 2-\square 3-\square 4-\square 5-\square
$$

8. Learning the idioms used in movie clips is important to a person because he can understand English-speaking films, videos, including the idioms better.

$$
1-\square \quad 2-\square \quad 3-\square \quad 4-\square \quad 5-\square
$$

9. Watching movie clips including the idioms can stimulate the students to ' figure out ' the meaning of newly encountered idioms by drawing from movie information.

$$
1-\square \quad 2-\square 3-\square \quad 4-\square 5-\square
$$

10. Watching movie clips including the idioms is important to the students so they can understand more English texts and books, including the idioms.

$$
\text { 1- } \square \quad \text { 2- } \square \quad 3-\square \quad 4-\square \quad 5 \text { - }
$$

11. It doesn't bother the students to use the idioms used in movie clips when speaking.

$$
1-\square \quad 2-\square \quad 3-\square \quad 4-\square \quad 5-
$$

12. Watching movie clips including the idioms make the students infer the meaning of unfamiliar idioms from the new situation.

$$
1-\square \quad 2-\square \quad 3-\square \quad 4-\square \quad 5-\square
$$

13. Watching movie clips including the idioms can be important because the students can interpret the figurative meaning of the idioms by using visualizers.

$$
1-\square \quad 2-\square \quad 3-\square \quad 4-\square \quad 5-\square
$$

14. The students can use movie clips including the idioms as a channel for their comprehension of the informal nature of certain idioms.

$$
1-\square \quad 2-\square \quad 3-\square \quad 4-\square \quad 5-\square
$$

15. Learning the idioms using movie clips is important to the students because without learning them masterly, the students feel something is missed.

$$
1-\square \quad 2-\square \quad 3-\square \quad 4-\square \quad 5-\square
$$

\section{REFERENCES}

[1] Beuscher, E., Robers, C. M., \& Schneider, W. (2005). Was erinnern Kinder von Lernfilmen? Psychologie in Erziehung und Unterricht, 52, 51-65.

[2] Boers, F. (1992). Raising metaphoric awareness. The Internet TESL Journal, Retrieved, 4,.11, November 1999, from http://nadabs.tripod.com/

[3] Clifford, B., Gunter, B., \& McAleer , J. (1995). Television and children: Program evaluation, comprehension, and impact. Hill sdale, NJ, England: Lawrence Erlbaum Associates.

[4] Cooper, T.C. (1998), Teaching Idioms. Foreign language Annuals. 31,3,266-335.

[5] Cooper, T. (1999). Processing of idioms by L2 learners of English. TESOL Quarterly 33, 233-62.

[6] Fazly, A. \& Cook, P. \& Stevenson, S. (2009). Unsupervised Type and Token Identification of Idiomatic Expression. Computational Linguistics 35,1, 61-103.

[7] Fernando ,C.(1996). "Idioms and Idiomaticity.” Oxford: Oxford University Press.

[8] Fine, J. (1988). "The place of Discourse in Second language study." In Research. Norwood NJ: Ablex, 1-16. Cambridge University Press p.35.

[9] Fisch, S. (2000). A capacity model of children's comprehension of educational content on television. Media Psychology, 2 , 6392.

[10] Fisch, S. McCann Brown, S. , \& Cohen, D. (2001). Young children's comprehension of educational television: the role of visual information. Media Psychology, 3, 365-378. 
[11] Gibbs, R.W.(1980).Spilling the beans on understanding and memory for idioms in conversation. Memory and cognition 8, 449456.

[12] Gibbs, R.W.(1992). What do idioms really mean? Journal of Memory and language, Retrived,4,.7. July 2000, from http://www.gse.uci.edu/ed168/resume.

[13] Gibbs, R. W. (1994). The poetics of mind: figurative thought, language, and understanding. Cambridge: Cambridge University Press.

[14] Graesser, A.C., Mio, J.,\& Millis ,k. k. (1989). Metaphors in Persuasive Communication. In D. Meutsch \& R. Viehoff (Eds.), Comprehension of literary discourse: Results and problems of interdisciplinary approaches (pp. 131-141). Berlin: Walter de Gruyter.

[15] Honeck, R.P. (1997). A proverb in mind: The cognitive science of proverbial wit and wisdom. Mahva, NJ: Erlbaum.

[16] Hudson, r. A.(1980). Sociolingusistics . Cambridge: Cambridge university press.

[17] Irujo, S. (1986). "Don't Put your leg in your mouth: transfer in the acquisition of idioms in a second language", TESOL Quarterly, 20, 287-304.

[18] Irujo, S. (1986). "A Piece of Cake: learning and teaching idioms." ELT Journal 40, 3, 236-242.

[19] King, J. (2002). "Motivating Learning Through Multimedia Film Projects" Unpublished Paper. Request at jane@mail.scu.edu.tw.

[20] Kovecses, Z. (1990). Emotion concepts. New York: Springer.

[21] Lakoff, G. (1987). Women, fire and dangerous things: what categories reveal about the mind. Chicago: Chicago University Press.

[22] Lewis, M.(1993). The lexical Approach. Hove: Teacher Training Publications, P.58.

[23] Marsh, E.J., \& Fazio, L.K. (2006). Learning errors from fiction: Difficulties in reducing reliance on fictional stories. Memory \& Cognition,34, 1140-1149.

[24] Massi, M.P., \& Merino, A. D. (1996). Films and EFL English Teaching Forum: 34, 20-24.

[25] Nattinger, T.R.\& Decarrio, J.s. (1992). Lexical Phrase and Language Teaching. Oxford: Oxford University press. P. 35.

[26] Nippold, M.A., Maron, C., \& Schwrrz, I. E. (2001). Idioms understanding in preadolescents: Synergy in action. American Journal of Speech-Language Pathology, 10, 169-181.

[27] Piaget, J. (1980). The psychogenesis of knowledge and its epistemological significance. In M. Piattelli-Palmarini (Ed.), Language and learning: The debate between Jean Piaget and Noam Chomsky (pp.22-34).Cambridge: MA: Harvard University Press.

[28] Quiang, N., Hai, T.\& Wolff, M. (2007). China EFL: Teaching with Movies. English Today, 23,2,39-46.

[29] Secules, T., Herron, T. \& Tomassello, M. (1992). The Effects of Video Context on Foreign Language Learning. The Modern Language Journal,76,4, 480-490.

[30] Seferoglu, G. (2008). Using feature films in language classes. Education Studies, 34,1,1-9.

[31] Silvia,P.J. (2008). Interest-the curious emotion. Current Direction in Psychological Science, 17, 57-60.

[32] Simpson, R. \& Mendis, D.(2003). A corpus-based study of idioms in academic speech. TESOL Quarterly, 37 (Fall) $419-441$.

[33] Sprenger, S., Levelt, W. J. M., \& Kempen, G. (2006). Lexical access during the production of idiomatic phrases. Journal of Memory and Language, 54, 161-184.

[34] Stempleski, S. (2000). "Video in the ESL classroom: Making the most of the movies". ESL Magazine, March/April, 2000. pp.10-12.

[35] Willis, D. (1990). The lexical syllabus. London: Harper.

[36] Ward, J. \& Lepeintre. (1996)."The creative connection in movies and TV: What Degrassi High teach teachers". The Journal in Language Learning and Teaching.1995-1996.

[37] Wray, A.(2000). "Holistic utterances in protolanguage: The link From Primates to human" in c. knight, M. Studdert-kennedy, and J. Hurford (Eds.), The Evolutionary Emergence of Language. Cambridge University Press. 285-302.

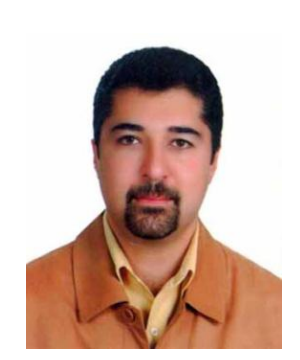

Omid Tabatabaei received his B.A. in translation in 1994 and M.A. in teaching English as a foreign language (TEFL) in 1997, and then his Ph.D in TEFL in 2007. He earned all the mentioned degrees from Iranian Universities.

He is presently an assistant professor at Islamic Azad University, Najafabad Branch, head of English Department and vice-dean of the Faculty of Humanities and Literature. He has published a couple of articles at national and international journals and presented papers at national and international conferences. His areas of interest are language acquisition, testing and assessment, teaching skills, and psycholinguistics.

Firooz Reisi Gahroei is an M.A. graduate student at Islamic Azad University, Najafabad Branch. He is a high school teacher and has taught at various language schools for about 10 years. 